\title{
Hubungan Celebrity Endorser Terhadap Perilaku Pembelian Produk Kecantikan Merek X
}

\author{
Elang Dewantara*1, Meita Santi Budiani ${ }^{2}$ \\ Universitas Negeri Surabaya \\ Jl. Lidah Wetan, Lidah Wetan, Kec. Lakarsantri, Kota SBY, Jawa Timur 60213 \\ *elang.170106664181@mhs.unesa.ac.id
}

\begin{abstract}
The purpose of the study was to find out the connectedness between celebrity endorsers and the purchasing behaviour of booming beauty products advertised by celebrity with initial FA. The technique of sampling or determination in this study is to use accidental sampling. In this study, data analysis techniques using Pearson Product Moment which aims to find correlation or relationship between celebrity endoser and $X$ product purchasing behavior. This study will use SPSS for windows version 25.0 help to perform correlational calculations. The results of this study showed the significance of both variables namely celebrity endorser with purchasing behavior is 0.000 and less than 0.005 (Sig. $<0.005$ ), pearson correlation value indicates a value of 0.744 . This indicates that the relationship of the two variables in this study is significantly related and categorized as strong. The contribution of celebrity endorser factor (variable $x$ ) to purchasing behavior (variable $y$ ) was $59.9 \%$.
\end{abstract}

Keywords: Celebrity Endorser, Purchasing Behavior, Beauty Products

Abstrak- Tujuan penelitian ini adalah untuk mengetahui keterhubungan antara celebrity endorser dengan perilaku pembelian dari produk kecantikan yang sedang booming yang diiklankan oleh selebgram FA. Teknik pengambilan atau penentuan sampel dalam penelitian ini adalah menggunakan accidental sampling. Pada penelitian ini teknik analisis data menggunakan Pearson Product Moment yang memiliki tujuan untuk mencari korelasional atau adanya hubungan antara celebrity endoser dengan perilaku pembelian produk X. Penelitian ini akan menggunakan bantuan SPSS for windows versi 25.0 untuk melakukan perhitungan korelasional. Hasil penelitian ini menunjukkan nilai signifikansi kedua variabel yaitu celebrity endorser dengan perilaku pembelian adalah 0,000 dan kurang dari 0,005 (Sig. < 0,005), nilai pearson correlation menunjukkan nilai 0,744 . Hal ini menandakan bahwa hubungan kedua variabel pada penelitian ini berhubungan secara signifikan dan dikategorikan kuat. Kontribusi faktor celebrity endorser (variabel $\mathbf{x}$ ) terhadap perilaku pembelian (variabel y) adalah sebesar $59,9 \%$.

Kata Kunci- Celebrity Endorser, Perilaku Pembelian, Produk Kecantikan

\section{PENDAHULUAN}

Pada masa pandemi yang disebabkan oleh virus yang bernama SARS-CoV-2 atau biasa disebut Covid19 mengharuskan semua pihak untuk memutar otak mencari alternatif untuk melakukan semua aktifitas mereka secara daring. Hampir seluruh aktifitas di lakukan secara daring, seperti bekerja (work form home), belajar (study form home), termasuk kegiatan perekonomian. Mayoritas kegiatan yang dilakukan di dalam rumah, mengharuskan pelaku ekonomi mau tidak mau beradaptasi dengan menggunakan media online, kegiatan penjualan online seringkali disebut dengan online shop. Karena bertambahnya jumlah online shop memaksa pemilik online shop untuk berinovasi untuk meningoptimalkan pemasarannya. Mayoritas online shop menggunakan platform media sosial sebagai sarana penyampaian produk. Media sosial adalah alat maupun cara yang digunakan oleh individu penyedia barang atau jasa untuk membagikan informasi melalui audio, gambar, teks, atau video [1].
Berdasarkan data yang diunggah oleh HootSuite khususnya pada konten "We are Social" yang merupakan situas layanan manajemen konten yang terhubung dengan berbagai situs jejaring sosial, pada bulan kedua 2020 mengungkapkan bahwa pengguna media sosial aktif di Indonesia sejumlah 160 juta orang [2]., dapat dilihat pada Gambar 1.

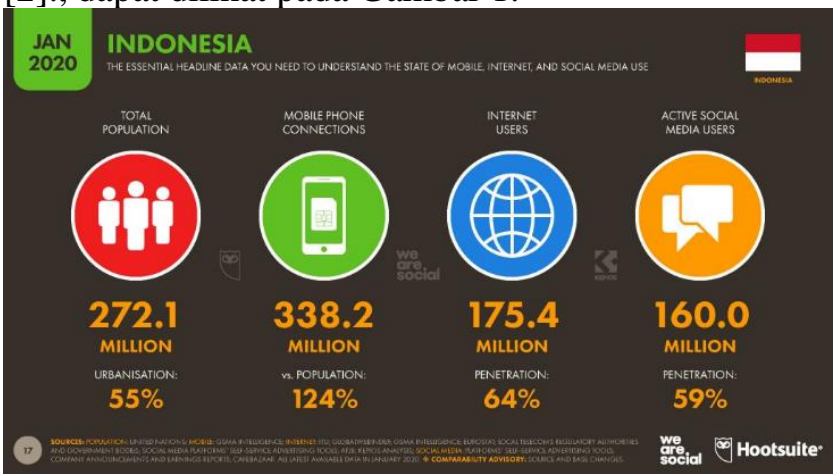

Gambar 1. Pengguna Media Sosial Aktif di Indonesia Sumber : [2] 
Angka tersebut menandakan bahwa terjadi peningkatan yang signifikan hingga 10 juta pengguna. Hal ini dikarenakan pada tahun 2019 jumlah pengguna media sosial di Indonesia sebanyak 150 juta orang [3]. Menggunakan media sosial untuk beraktifitas seperti menjadi new lifestyle khususnya di masa pandemi. Selain sebagai sarana komunikasi dan pencarian informasi, media sosial juga digunakan untuk mengembangkan perilaku konsumen dalam melakukan pembelian. Saat sebelumnya masyarakat mayoritas melakukan kegiatan pembelian melalui toko fisik, saat ini mau tidak mau kegiatan tersebut sebagian besar dialihkan secara daring. Hal ini tentu memberikan pengaruh yang signifikan terhadap perilaku konsumen.

Perilaku konsumen dengan adanya perubahan sarana pembelian produk telah berganti dari yang dapat mencoba produk secara langsung berubah dan tercukupi hanya dengan melihat informasi yang ada di media sosial tanpa pelru mencoba. Konsumen dapat membeli barang dengan duduk di depan laptop atau hanya dengan melihat melalui smartphone untuk memesan barang kesukaannya. Hal ini tentu sangat memudahkan konsumen, selain kegiatan dapat dilakukan dalam waktu yang singkat, hal ini juga dapat melindungi konsumen dari paparan COVID-19.

Kegiatan belanja online adalah suatu inovasi komunikasi yang tidak perlu adanya tatap muka secara langsung, namun cukup dilakukan terpisah dari dan ke seluruh dunia melalui media notebook, komputer atau smartphone yang terhubung dengan internet [4]. Kembali ke perilaku konsumen dalam kegiatan belanja online yang hanya cukup dilihat dari informasi yang disediakan penyedia produk, maka perlu adanya pemikiran matang perihal pemasaran produk di media sosial.

Pemasaran merupakan hal yang krusial untuk meraih konsumen. Tujuan dari kegiatan pemasaran yaitu mempromosikan produk atau jasa [5]. Dalam hal ini pemilik online shop harus mampu mengidentifikasi, membuat tafsiran mengenai kebutuhan dan keinginan pembeli atau konsumen, harus jeli dalam menetapkan harga, memikirkan pendistribusian produk dengan matang, menelaah data pasar termasuk lokasi, jumlah, dan sasaran konsumen, selain itu juga mencari cara promosi yang efektif dan efisien [6].

Pemasaran memerlukan adanya suatu strategi atau yang disebut dengan strategi pemasaran. [7] strategi pemasaran merupakan suatu pendekatan utama yang digunakan untuk mencapai sasaran yang didasari oleh target pasar, penempatan produk di pasar, serta tingkat harga. Strategi pemasaran menyangkut keunikan dari produk, kualitas produk, serta cara penawaran produk [8]. Strategi pemasaran akan mempengaruhi proses pengambilan keputusan konsumen.

Tahapan demi tahapan yang mempengaruhi seorang konsumen untuk membeli barang atau jasa merupakan pengertian dari proses pengambilan keputusan konsumen [9]. Penelitian terdahulu mengemukakan lima tahapan dalam proses pengambilan keputusan pembelian yaitu pengenalan permasalahan, pencarian informasi, evaluasi alternatif, perilaku pembelian, dan perilaku pasca pembelian [10]. Konsumen memutuskan untuk membeli suatu produk dikarenakan adanya ketertarikan untuk mencoba, menggunakan, atau memiliki produk tersebut [1]. Tindakan konsumen untuk membeli produk disebut dengan perilaku pembelian [9]. Ketika individu memutuskan untuk membeli maka hal ini disebut dengan perilaku pembelian.

\section{KAJIAN PUSTAKA}

Perilaku pembelian suatu produk oleh konsumen sangat dipengaruhi oleh faktor psikologis individu seperti karakteristik budaya, sosial, keluarga, peran, usia, tahapan siklus hidup, pekerjaan, status ekonomi, konsep diri, kepribadian, serta gaya hidup [10]. menyebutkan bahwa perilaku pembelian merupakan suatu pemahaman dari individu (konsumen) perihal kebutuhan maupun keinginan terhadap suatu produk dengan melakukan suatu penilaian serta pengidentifikasian alternative [11]. Perilaku pembelian oleh konsumen dipengaruhi pula oleh kesadaran konsumen terhadap adanya resiko pembelian yang kemungkinan besar akan dihadapi. Selain itu pengaruh dari orang terdekat juga tidak dipungkiri akan mempengaruhi perilaku pembelian oleh konsumen. Hal ini menandakan bahwa psikologis memiliki peranan besar terhadap keputusan pembelian konsumen [12].

Perilaku pembelian dipengaruhi oleh lima hal yaitu jenis produk, keputusan merek, keputusan penjual, keputusan waktu, serta jumlah pembelian. Penelitian terdahulu memiliki beberapa pandangan mengenai aspek dari perilaku pembelian yang meliputi; (1) adanya kebutuhan konsumen yang bisa dipenuhi oleh perusahaan; (2) perusahaan yang mampu memberikan informasi mengenai produk yang dibutuhkan oleh konsumen; (3) perusahaan mampu menonjolkan produk sehingga konsumen memilih perusahaan dibanding pesaingnya; (4) keputusan 
konsumen untuk membeli produk dari perusahaan; serta (5) adanya perasaan puas dari konsumen terhadap perusahaan [1].

Penelitian terdahulu mengemukakan tiga proses ketika seseorang menunjukkan perilaku pembelian [13]. Pertama, adalah fully planned purchase yaitu proses yang terjadi ketika keterlibatan dengan produk yang tinggi atau keterlibatan pembelian yang rendah. Kedua, partially planned purchase yaitu proses yang terjadi ketika seseorang memiliki keinginan untuk membeli produk yang sudah ada namun menunda karena mempertimbangkan merek. Ketiga, unplanned purchase yaitu proses yang terjadi ketika seseorang membeli produk secara spontan karena katalog atau pajangan atau iklan yang ditampilkan perusahaan.

Penelitian terdahulu menjabarkan beberapa hal yang mempengaruhi perilaku pembelian yaitu meliputi produk, harga, tempat, promosi, dan lingkungan sosial. Produk dalam hal ini memiliki pengertian atribut baik yang terlihat maupun tidak yaitu meliputi pengemasan, warna, mutu, serta merek maupun reputasi dari penyedia layanan [14]. Kemudian ada harga dimana harga sendiri memiliki beberapa pertimbangan kelompok yang harus diperhatikan, sebagai berikut:

1. Value is low price : pandangan bahwasanya hal yang paling penting adalah harga murah dibanding dengan nilai atau kualitas.

2. Value is whatever $i$ want in a product or services: pandangan bahwa nilai merupakan suatu hal yang dapat memberikan kepuasan terhadap keinginan.

3. Value is the quality $i$ get for the price $i$ pay : pandangan bahwa nilai yang diterima haruslah sesuai dengan harga yang telah dikeluarkan.

4. Value is what $i$ get for what $i$ give : pandangan bahwa nilai ditentukan dari besarnya manfaat yang diterima serta dilakukan perbandingan dengan uang yang dikeluarkan, waktu, dan usahanya [15].

Setelah harga, hal selanjutnya yang perlu diperhatikan adalah tempat. Tempat berkaitan dengan kemudahan akses untuk atau dalam hal ini dapat dikatakan distribusi dari produk sehingga konsumen tidak perlu waktu yang lama dan tempat yang jauh untuk mendapatkan produk. Namun jika membeli produk secara online faktor tempat tidak berpengaruh secara signifikan. Selanjutnya adalah promosi yang sangat penting dalam perilaku pembelian karena dalam hal ini promosi merupakan alat komunikasi untuk membujuk konsumen agar membeli produknya.

Promosi ini dapat bermacam-macam seperti memberikan sampel produk kepada konsumen sebagai alat untuk uji coba, memberikan penawaran pemberian produk khusus sebagai insentif setelah membeli suatu produk, memberikan pengurangan atau potongan harga (discount), dan adanya suatu event atau kegiatan khusus seperti sebuah kontes menggunakan produk. Seorang konsumen dapat menunjukkan perilaku pembelian karena tergiur akan promosi yang diberikan. Saat belanja online promosi dapat berupa bebas ongkos kirim atau juga potongan harga ketika membayar dengan uang virtual. Faktor sosial meliputi adanya kelompok acuan seperti pengaruh dari idola, profesional, atau rekan kerja; kemudian kelyarga juga dapat memberikan pengaruh terhadap pola konsumsi seorang individu; peran dan status sebagai penanda identitas dan alat komunikasi untuk menunjukkan peran dan statusnya kepada masyarakat.

Terdapat banyak faktor yang mempengaruhi perilaku pembelian konsumen, salah satu faktornya adalah celebrity endorser. [16] mengungkapkan bahwasanya celebrity endorser merupakan sebuah strategi untuk mempromosikan produk kepada pelanggan atau target pemasaran. Selain melakukan sebuah analisa pasar, kebutuhan para produsen saat ini ialah menggunakan jasa selebritis untuk memasarkan produk maupun merek mereka sebagai sebuah identitas. Hal ini merupakan sebuah strategi yang efektif untuk meraih profit atau keuntungan.

[17] mengemukakan bahwasanya perilaku pembelian khususnya online dipengaruhi oleh informasi yang disediakan perusahaan mengenai produk tersebut, desain produk yang menarik, dan kemudahan transaksi saat membeli produk. Perilaku pembelian juga tidak dapat dipungkiri bahwa dapat dipengaruhi oleh sarana promosi produk, salah satu sarana promosi yang efektif adalah melalui iklan. Saat memperkenalkan produk melalui iklan maka salah satu bagian yang paling penting adalah pemilihan bintang iklan (celebrity endorser).

Celebrity endorser adalah suatu cara mempromosikan suatu barang atau jasa melalui seorang artis, entertainer, atlet, atau publik figur yang banyak diketahui oleh mayoritas masyarakat dengan mempertimbangkan karakter khususnya yang sesuai dengan produk yang dipasarkan atau diiklankan [18]. Adapun atribut yang perlu dipertimbangkan pada saat memilih celebrity endorser adalah keahlian, keterampilan, pengerahuan, pengalaman, kecerdasan, sifat, kecantikan, keberanian, dan prestasi [19]. Penggunaan celebrity endorser adalah untuk menarik perhatian khalayak dengan harapan dapat meningkatkan awareness produk di masyaraat. Celebrity endorser dapat memberikan kesan bahwa

\section{(i) (2)}

$\underline{\text { Business Innovation and Entrepreneurship Journal (BIEJ) is published under licensed of a CC BY-SA Creative Commons }}$ Attribution-ShareAlike 4.0 International License. 
konsumen adalah individu yang selektif dalam memilih serta meningkatkan status dengan mempunyai produk yang juga digunakan oleh seorang selebritis. Celebrity endorser juga digunakan untuk memberikan asosiasi positif terhadap produk yang dipasarkan [20]. Indikator dari celebrity endorser ada tiga yaitu attractivenes endorser (daya tarik), credibility (kepercayaan), dan power (keahlian) [18].

Pada beberapa penelitian diungkapkan bahwa celebrity endoser mempengaruhi keputusan pembelian dan menghasilkan temuan bahwasanya setiap indikator yang dimiliki oleh celebrity endorser berkontribusi secara positif terhadap keputusan pembelian [5], [6], [19], [21], [22]. [21] pada penelitiannya menghasilkan temuan bawa dukungan pemasaran dari seorang selebriti menjadi pusat daya tarik bagi konsumen. Menurut hasil penelitian ini iklan yang dipasarkan oleh seorang selebriti memberikan rasa bahwa produk tersebut dapat dipercaya. Dengan kata lain celebrity endorser berpengaruh secara positif terhadap keputusan pembelian konsumen. Bedanya, dalam penelitian ini produk yang diteliti adalah produk yang sedang booming serta pelaksanaan di saat pandemi dimana belanja online sedang sangat gencar dilaksanakan.

Memilih celebrity endorser memerlukan sebuah ketepatan. Ketepatan didasari oleh atribut yang melekat pada endorser tersebut [23]. Jika selebriti yang memasarkan memiliki suatu fokus dan prestasi di bidang tersebut akan menambah nilai kepercayaan kepada konsumen. Maka dari itu penting untuk memikirkan secara matang jenis produk serta selebriti yang pas untuk memasarkan agar pemasaran menjadi tepat sasaran.

\section{METODE PENELITIAN}

Metode dalam penelitian ini menggunakan pendekatan kuantitatif. Teknik pengambilan atau penentuan sampel dalam penelitian ini adalah menggunakan accidental sampling. Accidental sampling merupakan sebuah teknik menentukan sampel yang didasari atas kebetulan dimana dalam hal ini secara kebetulan peneliti bertemu secara insidental dengan konsumen produk kecantikan merek $\mathrm{X}$ dan cocok untuk dijadikan sumber data dan bersedia menjadi sampel penelitian [25]. Pengumpulan data menggunakan alat ukur atau instrumen penelitian yang berisi aspek-aspek variabel terkait, analisis data dalam penelitian ini bersifat kuantitatif yang bertujuan untuk menguji hipotesis.
Pada penelitian ini teknik analisis data menggunakan Pearson Product Moment yang memiliki tujuan untuk mencari korelasional atau adanya hubungan antara celebrity endoser dengan perilaku pembelian produk $x$. Penelitian ini akan menggunakan bantuan SPSS for windows versi 25.0 untuk melakukan perhitungan korelasional.

Lokasi penelitian untuk memperoleh data primer dalam penelitian ini dilakukan secara online dimana peneliti akan menyebarkan instrumen penelitian berupa angket melalui google forms dan tidak terbatas pada lokasi. Populasi dalam penelitian ini adalah pengguna produk kecantikan X. Untuk sampel dalam penelitian ini adalah perempuan usia 1635 tahun yang menggunakan produk $\mathrm{X}$ dan mengetahui produk tersebut dan merupakan followers publik figur (FA).

Variabel bebas (indepedent) dalam penelitian ini adalah variabel yang ingin diketahui pengaruhnya atau memiliki pengaruh terhadap variabel lain. Pada penelitian ini variabel bebas adalah celebrity endoser. Sedangkan variabel terikat atau dependent adalah variabel yang dipengaruhi oleh variabel bebas dimana dalam hal ini variabel terikatnya adalah keputusan pembelian.

Perilaku pembelian pada penelitian ini memiliki definisi operasional yaitu kondisi ketika konsumen memutuskan untuk membeli suatu produk dikarenakan adanya ketertarikan untuk mencoba, menggunakan, atau memiliki produk tersebut. Definisi operasional dari celebrity endoser adalah suatu cara mempromosikan suatu barang atau jasa melalui seorang artis, entertainer, atlet, atau publik figur yang banyak diketahui oleh mayoritas masyarakat dengan mempertimbangkan karakter khususnya yang sesuai dengan produk yang dipasarkan atau diiklankan.

Teknik pengumpulan data pada penelitian ada dua yaitu data primer dan data sekunder. Data primer dalam penelitian ini adalah pemberian kuisioner yang mengacu pada skala perilaku pembelian dan skala celebrity endoser. Sifat pembagian kuisioner dilakukan secara tertutup dan responden akan diminta untuk memilih satu jawaban dari pilihan yang tersedia. Kuisioner dalam penelitian ini menggunakan skala satu sampai empat. Penggunaan skala untuk pengukuran persepsi, pendapat, maupun sikap dari seseorang terhadap suatu hal di sekitarnya. Data sekunder dalam penelitian ini dicari dengan membaca literatur, buku, atau sumber lainnya yang terkait dalam penelitian ini. 
Uji validitas dalam penelitian ini memiliki tujuan untuk menguji kelayakan dari setiap instrumen yang berupa pertanyaan atau pernyataan suatu variabel. Dalam penelitian ini peneliti akan melakukan korelasi jawaban responden dengan menghubungkan masing-masing aitem dengan skor totalnya. Perhitungan ini akan dilakukan dengan rumus corrected aitem-correlations dengan SPSS for windows 25.0. Aitem dinyatakan valid jika memiliki nilai aitem lebih dari 0,3 (skor aitem $>0,3$ ). Sebaliknya jika nilai aitem kurang dari 0,3 (skor aitem $<0,3$ ) maka aitem dinyatakan tidak valid. Berdasarkan hasil try out yang telah dilakukan kepada 30 responden maka memperoleh hasil; (1) satu dari 20 aitem pada skala celebrity endorser gugur karena nilai aitem 0,250; (2) tiga dari 40 aitem pada skala perilaku pembelian gugur karena nilai aitem 0,$260 ; 0,238 ; 0,214$. Berdasarkan data tersebut maka untuk skala celebrity endorser terdapat 19 aitem pertanyaan dan terdapat 37 aitem pada skala perilaku pembelian.

Uji reliabilitas dalam penelitian ini memiliki tujuan untuk menguji apakah instrumen yang digunakan dalam penelitian ini dapat dipercaya sebagai alat pengumpulan data. Perhitungan ini akan dilakukan dengan rumus Alpha Cronbach dengan SPSS for windows 25.0. Alat ukur dikatakan reliabel jika memiliki nilai Alpha Cronbach lebih dari 0,60 (Alpha Cronbach > 0,60). Try out yang dilakukan kepada 30 responden menghasilkan nilai Alpha Cronbach untuk skala celebrity endorser sebesar 0,887. Nilai Alpha Cronbach skala perilaku pembelian sebesar 0,932. Maka kedua skala dapat dijadikan alat ukur karena bersifat reliabel.

Analisis data pada penelitian ini menggunakan Pearson Product Moment dengan SPSS for windows 25.0.Namun sebelumnya akan dilakukan uji asumsi dan uji hipotesis terlebih dahulu. Uji asumsi merupakan langkah awal yang terdiri dari uji normalitas dengan uji Kolmogrov Smirnov dan lineritas dengan menggunakan Test for Linearty. Uji hipotesis menggunakan Perason Product Moment untuk mengetahui hubungan variabel $\mathrm{x}$ dan $\mathrm{y}$.

\section{HASIL DAN PEMBAHASAN}

\section{A. Uji Asumsi Klasik}

Kuisioner yang telah diisi oleh 140 responden selanjutnya dilakukan uji asumsi klasik berupa uji normalitas dan juga uji linieritas. Uji normalitas perlu dilakukan untuk mengetahui apakah data yang telah diperoleh berdistribusi normal atau tidak [26]. Pada penelitian ini uji normalitas dilakukan dengan menggunakan Kolmogrov Smirnov yang dilakukan dengan menggunakan bantuan SPSS 25.0 for windows. Adapun dua syarat untuk melihat normalitas data yaitu dengan membandingkan nilai signifikansinya. Apabila nilai signifikansi data penelitian bernilai lebih dari 0,05 (sig. > 0,05) maka data dikategorikan berdistribusi normal. Sebaliknya, jika signifikansi data penelitian bernilai kurang dari 0,05 (sig. < 0,05) maka data dikategorikan tidak berdistribusi normal. Berikut adalah tabel untuk memudahkan kategorisasi normalitas data.

Tabel 1. Hasil Uji Normalitas

\begin{tabular}{|c|c|c|c|}
\hline & & $\begin{array}{l}\text { Celebrity } \\
\text { endorser }\end{array}$ & $\begin{array}{c}\text { Perilaku } \\
\text { Pembelian }\end{array}$ \\
\hline \multicolumn{2}{|c|}{$\mathbf{N}$} & 140 & 140 \\
\hline \multirow{2}{*}{$\begin{array}{c}\text { Normal } \\
\text { Parameters }^{\mathrm{a}, \mathrm{b}}\end{array}$} & Mean & 63.61 & 126.91 \\
\hline & $\begin{array}{c}\text { Std. } \\
\text { Deviation }\end{array}$ & 4.912 & 9.630 \\
\hline \multirow{3}{*}{$\begin{array}{c}\text { Most } \\
\text { Extreme } \\
\text { Differences }\end{array}$} & Absolute & .131 & .084 \\
\hline & Positive & .131 & .079 \\
\hline & Negative & -.089 & -.084 \\
\hline \multicolumn{2}{|c|}{ Test Statistic } & .131 & .084 \\
\hline \multicolumn{2}{|c|}{ Asymp.Sig. (2-tailed) } & $.121^{\mathrm{d}}$ & $.255^{\mathrm{d}}$ \\
\hline
\end{tabular}

Berdasarkan data yang telah dianalisis menggunakan SPSS 25 for windows maka dapat diketahui untuk normalitas data variabel $\mathrm{x}$ dan variabel y pada penelitian ini sebagai berikut.

Berdasarkan tabel 6 di atas maka dapat diketahui hasil uji normalitas data dengan menggunakan Kolmogrov-Smirnov untuk variabel $\mathrm{x}$ yaitu celebrity endorser memiliki nilai signifikansi sebesar 0,121 dan lebih besar dari 0,05 maka data variabel $\mathrm{x}$ berdistribusi normal. Untuk variabel perilaku pembelian (variabel y) diperoleh nilai signifikansi sebesar 0,255 dan lebih dari 0,05 maka data variabel y berdistribusi normal. Maka dari itu kedua data baik variabel $\mathrm{x}$ (celebrity endorser) maupun variabel y (perilaku pembelian) pada penelitian ini berdistribusi normal karena kedua variabel memiliki nilai signifikansi lebih dari 0,05.

Setelah mengetahui bahwa kedua variabel memiliki data yang berdistribusi normal, selanjutnya adalah menguji linieritas kedua data. Uji linieritas penting dilakukan untuk mengetahui hubungan antara kedua variabel apakah bersifat linier atau tidak. Adapun dua syarat untuk melakukan uji lineritas adalah dengan melihat linierity dan 
deviation from linierity melalui analisis SPSS 25.0 for windows [25].

Penetapan linieritas data dengan melihat linierity memperhatikan nilai signifikansi kedua variabel. Jika nilai signifikansi linierity data penelitian bernilai lebih dari 0,05 (Sig. > 0,05) maka data tidak bersifat linier. Sebaliknya, jika nilai signifikansi linierity data bernilai kurang dari 0,05 (Sig. < 0,05) maka data bersifat linier.

Tabel 2. Hasil Uji Linieritas berdasarkan Linierity

$\begin{array}{ll}\text { Nilai } & \text { Keterangan } \\ \text { Signifikansi } & \end{array}$

\section{Celebrity}

endorser*

Perilaku

0,000 Linier

\section{Pembelian}

Uji linieritas kedua dilakukan dengan melihat deviation from linierity. Adapun syaratnya berbeda dengan linierity. Untuk pengujian data dengan deviation from linierity jika nilai signifikansi yang diperoleh melalui analisis SPSS bernilai lebih dari 0,05 (Sig. > 0,005) maka data bersifat linier. Sebaliknya jika nilai signifikansi bernilai kurang dari 0,05 (Sig. $<0,05$ ) maka data bersifat tidak linier.

Tabel 3. Hasil Uji Linieritas berdasarkan Deviation from Linierity

\begin{tabular}{lcc}
\hline & $\begin{array}{l}\text { Nilai } \\
\text { Signifikansi }\end{array}$ & Keterangan \\
\hline $\begin{array}{l}\text { Celebrity } \\
\text { endorser* }\end{array}$ & 0,272 & Linier \\
$\begin{array}{l}\text { Perilaku } \\
\text { Pembelian }\end{array}$ & & \\
\hline
\end{tabular}

Hasil analisa pada SPSS 25.0 for windows menunjukkan hasil uji linieritas kedua variabel berdasarkan linierity bernilai 0,000 dan kurang dari 0,05 . Berdasarkan hal ini maka dapat diketahui bahwa variabel x yaitu celebrity endorser dan variabel y yaitu perilaku pembelian bersifat linier.

Tabel di atas menunjukkan perolehan nilai signifikansi kedua variabel pada penelitian ini yaitu celebrity endorser dengan perilaku pembelian bernilai 0,272 . Hal ini menandakan bahwa variabel penelitian ini bersifat linier karena nilai signifikansi yang bernilai lebih dari 0,05 .

Berdasarkan hasil uji linieritas yang didasarkan pada linierity maupun deviation from linierity pada penelitian ini maka kedua variabel yaitu celebrity endorser dan perilaku pembelian bersifat linier.

B. Uji Hipotesis

Pada penelitian ini menggunakan uji hipotesis korelasi product moment. Adapun tujuan penggunaan korelasi product moment ialah untuk mengetahui ada atau tidaknya korelasi atau hubungan antara kedua variabel pada penelitian ini yaitu variabel celebrity endorser dengan perilaku pembelian. Uji hipotesis menggunakan bantuan SPSS 25.0 for windows.

Untuk pengambilan keputusan korelasi atau hubungan kedua variabel apakah bersifat signifikan atau tidak adalah dengan melihat nilai signifikansi yang diperoleh dari perhitungan SPSS. Apabilai nilai signifikansi yang diperoleh bernilai kurang dari 0,005 (Sig. < 0,005) maka hubungan antara kedua variabel dikatakan bersifat signifikan. Sebaliknya, jika nilai signifikansi lebih dari 0,005 (Sig. > 0,005) maka hubungan antara kedua variabel bersifat tidak signifikan. Ketentuan mengenai signifikansi korelasi dapat dilihat pada tabel berikut:

Penelitian ini memiliki hipotesis yang menyebutkan bahwa terdapat hubungan antara variabel x yaitu celebrity endorser dengan variabel y yaitu perilaku pembelian. Uji hipotesis pada penelitian ini menggunakan uji product moment dengan bantuan analisa dari SPSS 25.0 for windows. Adapun hasil uji hipotesis kedua variabel penelitian ini adalah sebagai berikut:

Tabel 4. Hasil Uji Hipotesis Product Moment

\begin{tabular}{ccrr}
\hline Celebrity & \multicolumn{1}{c}{ Celebrity } & \multicolumn{1}{c}{ Perilaku } \\
& $\begin{array}{c}\text { Pearson } \\
\text { correlation }\end{array}$ & 1 & $.774^{* * *}$ \\
\cline { 2 - 4 } & $\begin{array}{c}\text { Sig. (2- } \\
\text { tailed) }\end{array}$ & & 0.000 \\
\cline { 2 - 4 } Perilaku & $\mathrm{N}$ & 140 & 140 \\
\hline $\begin{array}{c}\text { Pearson } \\
\text { correlation }\end{array}$ & $.774^{* *}$ & 1 \\
\cline { 2 - 4 } & $\begin{array}{c}\text { Sig. (2- } \\
\text { tailed) }\end{array}$ & 0.000 & \\
\cline { 2 - 4 } & $\mathrm{N}$ & 140 & 140 \\
\hline
\end{tabular}

Berdasarkan data yang ditunjukkan pada tabel 13 di atas maka dapat diketahui nilai signifikansi kedua variabel yaitu celebrity endorser dengan perilaku pembelian adalah 0,000 dan kurang dari 0,005 (Sig. < 0,005). Hal ini menandakan bahwa kedua variabel memiliki hubungan yang signifikan. Di sisi lain nilai pearson correlation menunjukkan nilai 0,774 . Hal ini menandakan bahwa hubungan kedua variabel pada penelitian ini dikategorikan kuat. Nilai positif yang ditunjukkan pada pearson correlation menandakan 
bahwa hubungan atau korelasi kedua variabel bersifat searah. Sifat searah dalam hal ini berarti semakin tinggi pengaruh celebrity endorser maka semakin tinggi pula kecenderungan untuk membeli produk. Sebaliknya semakin rendah pengaruh celebrity endorser maka kecenderungan untuk membeli produk akan semakin rendah. Berdasarkan hal tersebut maka hipotesis yang tertuang pada penelitian ini yang menyebutkan bahwa terdapat hubungan antara celebrity endorser dengan perilaku pembelian dapat diterima.

Persentase nilai korelasi antara variabel celebrity endorser dengan perilaku pembelian dapat diketahui melalui hasil nilai R Square yang dianalisis menggunakan bantuan SPSS 25 for windows. Nilai $\mathrm{R}$ Square yang ditunjukkan akan menjelaskan besaran kontribusi hubungan antara variabel $\mathrm{x}$ dan $\mathrm{y}$ pada penelitian ini. Adapun hasil analisis R Square kedua variabel pada penelitian ini adalah sebagai berikut.

\begin{tabular}{clrrr} 
Model & $\mathbf{R}$ & $\begin{array}{c}\text { Tabel 5. Hasil Uji R Square } \\
\text { Square }\end{array}$ & $\begin{array}{c}\text { Adjusted } \\
\text { R Square }\end{array}$ & $\begin{array}{c}\text { Std. } \\
\text { Error of } \\
\text { the } \\
\text { Estimate }\end{array}$ \\
\hline $\mathbf{1}$ & $.774^{\mathrm{a}}$ & 0.599 & 0.597 & 6,117 \\
\hline
\end{tabular}

$\mathrm{R}$ Square variabel $\mathrm{X}$ dan Y pada penelitian ini yang tertera pada tabel 11 menunjukkan hasil 0,599. Hal ini berarti kontribusi faktor celebrity endorser (variabel X) terhadap perilaku pembelian (variabel Y) adalah sebesar $59,9 \%$. Sedangkan sisanya yaitu $40,1 \%$ adalah kontribusi dari faktor lainnya.

Penelitian ini memiliki tujuan untuk mengetahui hubungan antara dua variabel yaitu variabel x celebrity endorser dengan variabel y yaitu perilaku pembelian. Hasil penelitian ini menunjukkan nilai signifikansi kedua variabel yaitu celebrity endorser dengan perilaku pembelian adalah 0,000 dan kurang dari 0,005 (Sig. < 0,005). Hal ini menandakan bahwa kedua variabel memiliki hubungan yang signifikan. Di sisi lain nilai pearson correlation menunjukkan nilai 0,932 . Hal ini menandakan bahwa hubungan kedua variabel pada penelitian ini dikategorikan sangat kuat. Nilai positif yang ditunjukkan pada pearson correlation menandakan bahwa hubungan atau korelasi kedua variabel bersifat searah. Sifat searah dalam hal ini berarti semakin tinggi pengaruh celebrity endorser maka semakin tinggi pula kecenderungan untuk membeli produk. Sebaliknya semakin rendah pengaruh celebrity endorser maka kecenderungan untuk membeli produk akan semakin rendah.
Hasil perhitungan $\mathrm{R}$ Square variabel $\mathrm{x}$ dan y pada penelitian ini yang tertera hasil 0,599 . Hal ini berarti kontribusi faktor celebrity endorser (variabel $\mathrm{x}$ ) terhadap perilaku pembelian (variabel y) adalah sebesar 59,9\%. Sedangkan sisanya yaitu 40,1\% adalah kontribusi dari faktor lainnya. Berdasarkan hal tersebut maka hipotesis yang tertuang pada penelitian ini yang menyebutkan bahwa terdapat hubungan antara celebrity endorser dengan perilaku pembelian dapat diterima.

Perilaku pembelian merupakan sebuah keputusan membeli produk atau merek yang dipilih dari berbagai alternatif yang tersedia. Penelitian ini menghasilkan temuan beberapa faktor yang mempengaruhi perilaku pembelian seseorang perilaku pembelian yaitu meliputi produk, harga, tempat, promosi, dan lingkungan sosial. Secara garis besar terdapat dua faktor utamanya adalah faktor situasional dan sikap orang lain. Dua hal ini mempunyai pengaruh yang signifikan sehingga faktor harga tidak terlalu dipermasalahkan [27]. Dua faktor utama ini dapat dimunculkan secara internal maupun eksternal. Secara internal, kebutuhan akan fungsi sebuah produk atau merek akan mempengaruhi perilaku pembelian. Secara eksternal dapat terjadi ketika individu menonton sebuah iklan yang dapat memunculkan keinginan untuk mencari informasi lebih lanjut mengenai produk atau merek yang dirasa pas dengan kebutuhannya.

Teori utama dalam penelitian ini dikemukakan oleh [17] yang menyatakan bahwasanya perilaku pembelian khususnya online dipengaruhi oleh informasi yang disediakan perusahaan mengenai produk tersebut, desain produk yang menarik, dan kemudahan transaksi saat membeli produk. Perilaku pembelian juga tidak dapat dipungkiri bahwa dapat dipengaruhi oleh sarana promosi produk, salah satu sarana promosi yang efektif adalah melalui iklan. Saat memperkenalkan produk melalui iklan maka salah satu bagian yang paling penting adalah pemilihan bintang iklan (celebrity endorser). [18] juga menambahkan bahwasanya celebrity endorser memiliki fungsi untuk mengenalkan produk atau sebuah merek kepada masyarakat secara luas melalui tokoh yang sebelumnya telah dikenal sehingga mampu memberikan pengaruh konsumen untuk memutuskan membeli produk tersebut. Selain itu celebrity endorser juga merupakan suatu strategi komunikasi alternatif antara produsen kepada konsumen mengenai produk atau merek yang ditawarkan. Mengingat betapa pentingnya fungsi dari celebrity endorser maka dalam memilih selebritis pun terdapat beberapa hal yang 
perlu diperhatikan seperti prestasi, kemudian cara komunikasi, sikap, maupun popularitasnya.

Popularitas celebrity endorser merupakan unsur yang memegang peranan yang sangat penting untuk memunculkan perilaku pembelian pada masyarakat. Pemilihan selebritis yang akan memasarkan atau mengiklankan produk atau merek mempengaruhi citra dan kredibilitas perusahaan. Popularitas selebritis yang di endorse atau celebrity endorser akan membentuk sebuah kesadaran pada konsumen karena ketika masyarakat sadar akan bintang iklan maka kesadaran terhadap produk juga akan meningkat [28]. Celebrity endorser akan bertugas menyampaikan informasi terkait dengan produk atau merek. Informasi yang disampaikan ini dapat menginternalisasi keyakinan, opini, sikap, maupun perilaku konsumen terkait dengan akurasi penyampaian.

Produk kecantikan merek X ini diinisiasi oleh salah satu aktris dan host ternama sebuah acara musik di televisi swasta besar di Indonesia, berinisial FA. Pemasaran produk ini pertama kali dilakukan di media sosial Instagram dimana saat ini akun instagram tersebut telah ter-verified dengan jumlah followers mencapai 2,8 juta orang. FA selain menjadi penggagas produk juga sebagai celebrity endorser atas produknya sendiri. FA sendiri memiliki followers sebesar 16 juta orang.

Produk kecantikan merek X merupakan salah satu produk yang masuk dalam kategori sukses dalam hal melakukan pemasaran oleh selebriti. Produk kosmetik merek X terdapat banyak jenisnya. Body scrub, body soap, shampoo, shower scrub, facial wash, acne serum adalah beberapa jenis produk yang bermerek X. Produk kecantikan merek X memang menyediakan berbagai jenis produk kecantikan disesuaikan dengan kebutuhan dari target pasar yaitu perempuan. Hal ini pun memudahkan konsumen untuk one stop shopping yaitu membeli banyak produk yang dibutuhkan dalam satu waktu dan satu tempat. Ditambah biasanya produk merek $\mathrm{X}$ menyediakan berbagai macam promosi jika konsumen membeli paketan produk yang ditawarkan yang tentunya dari segi harga akan lebih murah.

Hasil penelitian menunjukkan terdapat atribut yang perlu dipertimbangkan pada saat memilih celebrity endorser adalah keahlian, keterampilan, pengerahuan, pengalaman, kecerdasan, sifat, kecantikan, keberanian, dan prestasi. Penggunaan celebrity endorser adalah untuk menarik perhatian khalayak dengan harapan dapat meningkatkan awareness produk di masyaraat. Celebrity endorser dapat memberikan kesan bahwa konsumen adalah individu yang selektif dalam memilih serta meningkatkan status dengan mempunyai produk yang juga digunakan oleh seorang selebritis [19].

Dalam penelitian ini, penulis menggunakan kategori selebgram berinisial FA sebagai celebrity endorser dari sebuah produk kecantikan. Berdasarkan hasil penelitian yang nampak dari 140 responden maka FA dapat dikategorikan memiliki implikasi yang kuat kepada konsumen hingga dapat mempengaruhi dan memunculkan perilaku pembelian terhadap produk kecantikan merek X. FA memiliki daya tarik, ahli dalam bidangnya atau mampu mengkomunikasikan produk merek X, serta dapat dipercaya.

Berdasarkan hasil penelitian serta pembahasan di atas maka hipotesis awal penelitian ini yang menyatakan bahwa terdapat hubungan antara celebrity endorser dengan perilaku pembelian produk kecantikan merek X dapat diterima. Implikasi praktis berdasarkan hasil ini adalah untuk meningkatkan perilaku pembelian produk kecantikan merek X maka harus meningkatkan celebrity endorser dan memperhatikan figur yang akan dipilih.

\section{KESIMPULAN DAN SARAN}

Hasil penelitian ini menunjukkan kedua variabel memiliki hubungan yang signifikan. Hal ini menandakan bahwa hubungan kedua variabel pada penelitian ini dikategorikan kuat. Nilai positif yang ditunjukkan pada pearson correlation menandakan bahwa hubungan atau korelasi kedua variabel bersifat searah. Sifat searah dalam hal ini berarti semakin tinggi pengaruh celebrity endorser maka semakin tinggi pula kecenderungan untuk membeli produk. Sebaliknya semakin rendah pengaruh celebrity endorser maka kecenderungan untuk membeli produk akan semakin rendah. Berdasarkan hal tersebut maka hipotesis yang tertuang pada penelitian ini yang menyebutkan bahwa terdapat hubungan antara celebrity endorser dengan perilaku pembelian dapat diterima.

Hasil penelitian ini menunjukkan kuatnya hubungan antara celebrity endorser terhadap perilaku pembelian konsumen. Penelitian ini juga sejalan dengan beberapa penelitian lainnya meskipun dengan produk dan merek yang berbeda. Hal ini mengindikasikan bahwasanya terdapat hubungan antara celebrity endorser dengan perilaku pembelian, maka dari itu bagi pembaca yang memiliki bisnis online shop disarankan dapat mempertimbangkan untuk melibatkan celebrity endorser dalam 
memasarkan produknya untuk meningkatkan pembelian konsumen. Online shop dapat merekrut selebriti untuk menjadi model untuk memasarkan produknya, hal ini karena popularitas selebritis yang di endorse atau celebrity endorser akan membentuk sebuah kesadaran pada konsumen karena ketika masyarakat sadar akan bintang iklan maka kesadaran terhadap produk juga akan meningkat. Celebrity endorser akan bertugas menyampaikan informasi terkait dengan produk atau merek. Informasi yang disampaikan ini dapat menginternalisasi keyakinan, opini, sikap, maupun perilaku konsumen terkait dengan akurasi penyampaian.

\section{REFERENSI}

[1] P. Kotler and K. . Keller, Marketing Management, 15th edition. Pearson Education, 2016.

[2] HootSuite, "The essential headline data you need to understand the state of mobile, internet, and social media use," 2020 . .

[3] HootSuite, "The essential headline data you need to understand the state of mobile, internet, and social media use," 2019. .

[4] T. . Nugroho, Sukses bisnis toko online trik melipatgandakan pasar untuk meraup untung yang lebih besar. Gramedia Pustaka Utama, 2010.

[5] D. A. A. Mubarok, "Pengaruh Celebrity Endorsement Terhadap Minat Beli Konsumen (Studi Pada Konsumen Mahasiswa Kelas Reguler Sore STIE INABA Bandung)," $J$. Indones. Membangun, vol. 3, no. 1, pp. 61-76, 2016.

[6] N. . Andrianto and E. Sutrasmawati, "Pengaruh celebrity dan brand image pada proses keputusan pembelian," J. Manag. Anal., vol. 5, no. 2, pp. 104-109, 2016, doi: 10.15294/MAJ.V5I2.8055.

[7] D. Sunyoto, Strategi pemasaran: konsep memenangkan persaingan bisnis dan menakar keberhasilan strategi menarik konsumen. CAPS, 2015.

[8] S. Hasibuan and F. Amela, "Implementasi quantitative strategic planning matrix (QSPM) dalam merencanakan strategi pemasaran pada usaha minuman happy bubble drink di kota Binjai," J. Bisnis Adm., vol. 8, no. 1, pp. 26-36, 2019.

[9] D. Marlius, "Keputusan pembelian berdasarkan faktor psikologis dan bauran pemasaran PT.
Intercom Mobilindo Padang," J. Pundi, vol. 1, no. 1, pp. 57-66, 2017, doi: https://doi.org/10.31575/jp.v1i1.9.

[10] P. Kotler and K. . Keller, Marketing Management, 14th edition. Pearson Education, 2012.

[11] B. Swasta and Irawan, Manajemen pemasaran modern. Liberty, 2006.

[12] A. Tjahjono, P. H. Semuel, R. Karina, J. M. Pemasaran, U. K. Petra, and J. Siwalankerto, "Analisa Marketing Mix , Lingkungan Sosial, Psikologi Online Pakaian Wanita," J. Manaj. Pemasar. Petra, vol. 1, no. 2, pp. 1-9, 2013.

[13] J. Blythe, Consumer behaviour. SAGE Publications Inc, 2013.

[14] S. C. Putri, "Pengaruh Media Sosial Terhadap Keputusan Pembelian Konsumen Cherie Melalui Minat Beli," PERFORMA J. Manaj. dan Start-Up Bisnis, vol. 1, no. 5, p. 594, 2016.

[15] V. . Zeithaml and M. . Bitner, Service marketing interating customer focus across the firm. Prentice Hall, 2006.

[16] E. Jaelani, "Pengaruh celebrity endorsement terhadap keputusan pembelian online pada konsumen produk x di Bandung," J. Sains Manaj. Akunt., vol. 10, no. 1, pp. 1-8, 2018.

[17] J. P. Shim, Y. B. Shin, and L. Nottingham, "Retailer web site influence on customer shopping: An exploratory study on key factors of customer satisfaction," J. Assoc. Inf. Syst., vol. 3, pp. 53-76, 2002.

[18] A. T. Shimp, Periklanan promosi. Erlangga, 2002.

[19] D. Pradhan, I. Duraipandian, and D. Sethi, "Celebrity endorsement : how celebrity - brand - user personality congruence affects brand attitude and purchase intention," J. Mark. Commun., vol. 22, no. 5, pp. 456-473, 2014, doi:

https://doi.org/10.1080/13527266.2014.91456 1.

[20] Q. Zafar and M. Rafique, "Impact of celebrity advertisement on customers' brand perception and purchase intention," Asian J. Bus. Manag. Sci., vol. 1, no. 11, pp. 53-67, 2012.

[21] A. Khan and S. Lodhi, "Influence of celebrity endorsement on consumer purchase decision : a case of Karachi," J. Interdiscip. Reseach, vol. 2, no. 1, pp. 102-111, 2016, doi: 10.1186/16871847-2012-104.

[22] K. Sukma, I. Nurcahya, and A. Suryani, 
"Pengaruh Celebrity endorser, Brand Image Dan Kepercayaan Terhadap Keputusan Pembelian Produk Pembersih Wajah Menâs Biore," None, vol. 5, no. 7, p. 248538, 2016.

[23] N. Fleck, M. Korchia, and I. Le Roy, "Celebrities in advertising: looking for congruence or likability?," Psychol. Mark., vol. 29, no. 9, pp. 651-662, 2012, doi: https://doi.org/10.1002/mar.20551.

[24] S. Arikunto, Prosedur penelitian suatu pendekatan praktik. Rineka Cipta, 2006.
[25] Sugiyono, Metode penelitian kuantitaif, kualitatif dan $r \& d$. Alfa Beta, 2018.

[26] Sugiyono, Statistika untuk penelitian. 2017, 2017.

[27] R. Sanditya, "Hubungan celebrity endorser dengan keputusan pembelian produk pakaian pada konsumen secara online di media sosial instagram," vol. 7, no. 1, pp. 100-104, 2019.

[28] M. Tjondrokoesoemo, "Celebrity endorser terhadap keputusan pembelian,” vol. 2, 2017. 